\title{
A FIGURA DE D. JOÃO III NA OBRA DE INÁCIO DE MORAIS
}

\author{
Aires Pereira do Couto*
}

\section{INTRODUÇÃO}

De entre as obras conhecidas de Inácio de Morais - um humanista a quem cabe um lugar de relevo na cultura portuguesa do século XVI, nomeadamente na literatura quinhentista novilatina ${ }^{1}$ — duas são dedicadas a D. João III. São elas:

- IGNATII MORA / LIS oratio panegyrica ad inuictissimum Lusi / taniae Regem diuum Ioannem tertium, nomine / totius Academiae Conimbricensis, atque / in eiusdem scolis habita, ipsa etiam / Regis coniuge augustissima / / diua Caterina Lusitaniae / regina, et regni haerede / principe filio diuo / / Ioanne / serenissimo eiusdemque regis sorore diua / Maria serenissima praesentibus.

- Ignatii Moralis oratio / funebris in interitum serenissimi regis Ioannis / /ad patres conscriptos Conimbricensis / Academiae./ Conimbricae. Anno M.D.LVII. / Excudebat Ioannes Aluarus Typogra / phus Regius, apud quem est / / uenalis. ${ }^{2}$

Da primeira destas obras - a Oratio panegyrica - existe, na Biblioteca Municipal do Porto, uma edição impressa ( sem qualquer referência ao local da impressão, ao impressor e à data) apensa, juntamente com outras orações latinas, às obras várias de Jorge Coelho, num volume, com a cota y'-3-58, que se encontra na Casa Forte da Biblioteca.

A partir deste exemplar da Biblioteca Municipal do Porto foi feita uma edição fac-símile publicada em 1937, em Coimbra, aquando do IV centenário do estabelecimento definitivo da Universidade nesta cidade.

Esta oração de Inácio de Morais nasceu do convite que, no dia 2 de Outubro de 1550, a Academia da Universidade de Coimbra, no Conselho em que se tratou da recepção de D. João III, endereçou ao próprio Inácio de Morais para que este proferisse, em nome da Universidade, uma oração de saudação àquele monarca,

* Faculdade de Letras — Pólo de Viseu da Universidade Católica Portuguesa. 
aquando da sua visita a Coimbra. ${ }^{3}$ Esta oração viria a ser pronunciada na sala grande dos Paços no dia 8 de Novembro, e foi "muito louvada e de muita autoridade"4.

Esta oração panegírica, pensada e escrita no espaço de um mês, apresenta uma estrutura semelhante à estabelecida pelos tratados de retórica ${ }^{5}$. Assim, no exordium, Inácio de Morais apresenta-se com humildade à ilustre assembleia, a Academia Conimbricense, mas reanima-se com a natural benevolência régia. Aproveita também para afastar qualquer suspeita de adulação. Na narratio, o humanista fala de D. João III, enaltecendo as suas qualidades humanas, religiosas, políticas e guerreiras; e destaca o seu importante apoio às artes e às letras. Através da confirmatio, Inácio de Morais apresenta provas concretas do que diz na narratio. Finalmente, na peroratio, o humanista sintetiza as qualidades de D. João III. ${ }^{6}$

Da segunda obra atrás citada - a Oratio funebris in interitum serenissimi regis Ioannis - existe um exemplar impresso, muito estragado e único, na Biblioteca Nacional do Rio de Janeiro (cota W.1.5.21).

Esta oração, que constitui uma das várias manifestações de luto da Academia Conimbricense pela morte de D. João $\mathrm{III}^{7}$, ocupa as folhas $\mathrm{A}^{v^{\circ}}$ a Bii ${ }^{v^{\circ}}$. Segue-se-lhe uma elegia à morte de D. João III, composta por 63 dísticos elegíacos e intitulada:

- In interitum serenissimi regis Lusitanorum Ioannis tertii Ignatii Moralis elegia.

e quatro epitáfios:

- Epithaphium piissimi regis Ioannis (constituído por 4 dísticos elegíacos)

- Aliud Epitaphium (3 dísticos elegíacos)

- Aliud (2 dísticos elegíacos)

- Aliud (8 hendecassílabos falécios)

À semelhança do que acontece com a Oratio panegyrica, também a estrutura desta oratio se aproxima da estabelecida pelos tratados de retórica. Deste modo, no exordium, Inácio de Morais salienta a profunda dor que o fere e a dificuldade que, neste ambiente de tristeza, sente em encontrar as palavras apropriadas para evocar os notáveis feitos de D. João III. Na narratio, o humanista refere a tristeza que atinge o povo português e relembra as qualidades de D. João III, realçando a brandura do seu carácter, a piedade, a generosidade, o seu sentimento religioso e a sua grandeza de espírito. Na confirmatio, Inácio de Morais apresenta exemplos vários que confirmam as qualidades régias apontadas e as razões que justificam a tristeza que envolve o povo português. Na peroratio, Inácio de Morais começa por lançar um apelo a Deus para que socorra o povo português nesta situação desesperada, conservando o império lusitano e prolongando a vida de D. Sebastião. 
Termina, pedindo aos professores da Universidade de Coimbra que, com preces e sacrifícios expiatórios, compensem os benefícios que receberam do rei e, com grata memória, honrem eternamente tão grande benemérito da Academia Conimbricense.

\section{O PROTECTOR DE INÁCIO DE MORAIS}

Inácio de Morais nutria por D. João III uma enorme admiração e uma profunda gratidão. A este monarca ficou Inácio de Morais a dever grande parte daquilo que ele foi ao longo da sua vida. Foi, de facto, graças à generosidade de D. João III que Inácio de Morais, na qualidade de bolseiro do rei, foi estudar para Paris, provavelmente em 1526. Ele próprio alude aos bolseiros de D. João III na sua Oratio panegyrica ad inuictissimum Lusitaniae regem diuum Ioannem tertium ${ }^{8}$ :

Na verdade, enviaste para Paris vários jovens para se cultivarem, a expensas tuas. ${ }^{9}$ (fl. Aiiij)

Mas a liberalidade do rei para com Inácio de Morais não se ficou apenas pela atribuição de bolsas de estudo. Foi também graças a ela que o humanista suportou as duras desventuras da vida. É o próprio Inácio de Morais que o afirma na sua Or. pan.:

É por experiência que digo isto, porque eu próprio, desde a mais tenra idade, suporto, com a tua liberalidade, rei clementíssimo, as duras desventuras da vida. Por isso sou levado a ter de te agradecer também por este favor pessoal (fl.C).

E confirma-o num passo da Oratio funebris in interitum serenissimi regis Ioan$n i{ }^{10}$ onde, recordando algumas das beneficiências régias, deixa transparecer a sua gratidão por tudo o que o rei fez por ele:

E além disso, todos sabeis quanta liberalidade teve igualmente para comigo. Com efeito, quão poucos há, em Portugal, que não sejam sustentados de alguma forma pelos auxílios régios? Para quem não dimanou alguma coisa daquela inesgotável fonte de liberalidade? A quem não concedeu ele generosamente benefícios? Donde provieram, pois, estes nossos estudos? Donde esta florescente Academia das letras? Donde tantos mosteiros? Tantos templos construídos? Tanto dinheiro gasto no apoio aos pobres? Tantas magníficas recompensas dadas aos beneméritos da nação? Tantos benefícios estabelecidos para os estudiosos das letras? Nunca negarei que eu faço parte desse número, eu que, quase desde os primeiros anos, vivo do tesouro régio e sou alimentado pelos favores régios. E mais ainda, a ele atribuo este conhecimento (qualquer que ele seja) recebido das belas artes; a ele devo os gastos quotidianos; estes agasalhos do corpo que trago nos ombros, a ele devo e sempre deverei (fl. Aiij). 
E preocupado, desorientado, Inácio de Morais interroga-se, agora que D. João III morreu, sobre o seu futuro e o de todos aqueles que eram apoiados pelo rei:

E agora, onde é que nós, pobres, privados do teu apoio, nos refugiaremos? Quem nos governará, a nós, por assim dizer ovelhas perdidas sem pastor? Pertubados pelas desgraças, quem nos ajudará? Quem levantará os que estão por terra? A quem, no mundo, imploraremos auxílio, para que nos socorra com um ar tão plácido, tão alegre e tão sereno? Finalmente, que outro soberano nos acarinhará com tão grande afeição? (Or. fun. fl. Aiij $\left.v^{0}\right)$.

É que, continua o humanista, o rei era a salvação do povo e, por isso, a sua morte feriu gravemente muitos daqueles que eram sustentados de alguma forma pelos auxílios régios:

A vida do rei era a nossa salvação; descansávamos com os olhos e pensamentos fixos nele. Agora, este golpe mais recente rasgou as velhas cicatrizes, e uma dor muito forte, caindo sobre nós, desgraçados, feriu-nos com mais força e derrubou-nos. Havíamos suportado, até agora, situações duras, penosas e tristes, mas agora o desfecho mais funesto e mais cruel desta tragédia surpreendeu-nos (Or. fun. fls. Aiiij vํ - B).

Agora, com a morte de tão grande benemérito, Inácio de Morais receia os perigos em que, porventura, cairão todos aqueles para quem D. João III era uma proteç̧ão - nostrum praesidium (v.12) - como lhe chama o poeta na sua elegia In interitum serenissimi regis Lusitanorum Ioannis tertii ${ }^{11}$. A morte de D. João III deixa o povo, em que Inácio de Morais se inclui, aterrorizado, sem saber o que fazer, pois diz o poeta:

A tua morte, terrível notícia, aterrorizou-nos a todos e um arrepio gélido subiu pelos duros ossos (El., vv.55-56).

\section{A PERSONALIDADE DO REI}

As referidas composições de Inácio de Morais não se limitam a ser um agradecimento e um reconhecimento por tudo o que o rei fez pelo humanista, em particular, e pelo povo, em geral. Elas transmitem-nos também inúmeros dados sobre a personalidade do rei, cujas qualidades o poeta não se cansa de elogiar.

As suas qualidades são tais que ultrapassam as de todos os reis. Por isso, diz Inácio de Morais, todos os seus súbditos agradecem a Deus o ter-lhes dado um tão notável soberano, cuja figura majestosa o distinguiu, logo desde o nascimento, entre todos os seus irmãos e o apontava facilmente não só como herdeiro do trono mas também para os maiores feitos:

Todo o povo português e todas as gentes que estão sob a tua soberania se congratulam pelo facto de, por auxílio e providência divina, nos ter cabido em sorte um tal prín- 
cipe que, pela piedade, pela justiça e bondade e, em suma, por todo o género de virtudes, ultrapassa todos os reis na nossa memória. (...) Todos, portanto, rei invictíssimo, te consideram realmente como um príncipe cristão e perfeito sob todos os aspectos; todos reconhecem que foste enviado pelo divino poder para o governo da nação. Na verdade, não só a própria dignidade do rosto mas também a figura majestosa, que se distinguiu logo desde o nascimento entre todos os teus irmãos, apontavam-te facilmente como herdeiro do ceptro paterno e nascido para os feitos mais importantes (Or. pan., fls. Aij $v^{\circ}-$ Aiij). ${ }^{12}$

No século XVI, a excelência e perfeição física e moral do príncipe eram atributos considerados indispensáveis na figura do governante ${ }^{13}$. A poesia da época deixa transparecer claramente este ideal de perfeição física e moral que o rei deve encarnar. Gil Vicente, na sua Tragicomédia Pastoril da Serra da Estrela, chama a D. João III “o mais fermoso Rei / que ha na face da terra."

Mas vejamos então quais são as qualidades que, segundo Inácio de Morais, fazem de D. João III o rei mais virtuoso.

Admirados por todos são o discernimento, a penetrante subtileza de pensamento e a prudência de D. João III:

Admiram todos o teu muito rigoroso juízo e a tua muito penetrante subtileza de pensamento, já que nada é tão ambíguo, nenhuma situação tão obscura e complicada que tu, com prudentíssimo raciocínio, não resolvas facilmente. (...) Em suma, como a prudência é a porta de todas as virtudes (como o afirmam homens sábios nos seus livros), daqui acontece que tenhas o hábito de examinar tudo cuidadosamente antes de procurares fazer alguma coisa, e que te agradem mais os sãos conselhos do que os impulsos temerários e cegos, impelidos pelos quais muitos chefes acabaram por perder-se eles e os seus cidadãos (Or. pan., fl.Aiij v ${ }^{\mathbf{o}}$ ).

Estas qualidades, nomeadamente a prudência, levam Inácio de Morais a compará-lo a Nestor, o famoso rei de Pilos que ficou célebre sobretudo pela sua prudência e eloquência:

Fazes lembrar, na verdade, aquela tão louvada prudência de Nestor que, quando falava, toda a Grécia admirava e submetia-se espontaneamente ao seu juízo (Or. pan., fl.Aiij $v^{\mathbf{o}}$ ).

Elogiada é também a sua memória, que dificilmente esquecia algo que tivesse fixado:

E diz-se também que a tua memória é de tal modo fiel e firme que, por esta fama, é também elogiada em todo o lado nas conversas do povo, e é de tal modo elogiada que muitos afirmam que, para ti, o que tenha sido gravado uma só vez na memória, com custo algum dia é arrancado (Or. pan., fl.Aiij vº).

Notável é considerado o seu amor pela sabedoria, que o levou a ter o cuidado de instruir e formar os seus súbditos, intrépidos e indomáveis por natureza, imi- 
tando, deste modo, o rei Numa Pompílio que conseguiu pacificar os intrépidos cidadãos romanos:

Da mesma fonte da prudência nasce aquele inacreditável amor pela sabedoria com que tu, expulsa a barbárie de Portugal, tiveste o cuidado de, por meio de todas as belas letras, instruir e formar muito bem os espíritos dos teus súbditos. Com efeito, como os nossos homens fossem, pela sua natureza, intrépidos e indomáveis, e estivessem mais habituados ao prazer de Marte do que ao das letras, não suportaste que vivessem por mais tempo nas trevas da ignorância. Nisto, imitaste Numa Pompílio que trouxe da guerra para o culto da religião e o amor da paz os intrépidos cidadãos romanos (Or. pan., fls. Aiij v ${ }^{\circ}$ - Aiiij).

Para isso, não só concedeu, como vimos, bolsas a vários estudantes portugueses para que pudessem ir estudar para o estrangeiro, mas também fundou em Coimbra uma nova Academia, capaz de competir com as universidades estrangeiras:

Na verdade, não só enviaste para Paris vários jovens para se cultivarem, a expensas tuas, como também erigiste aqui uma nova Academia de Letras que pode não só competir com as escolas estrangeiras de todos os povos, mas que também parece fazer voltar para estes nossos tempos a velha Atenas. Na realidade que género de disciplina há que aqui não floresça extraordinariamente, e no qual, em tão poucos anos, à força de trabalho, a juventude portuguesa não haja saído cultivadíssima? (Or. pan. fl. Aiiij).

Inácio de Morais recorda que, ao transferir a Universidade para Coimbra em 1537, D. João III contratou um corpo docente praticamente novo, mandando vir de toda a parte mestres portugueses ou estrangeiros, muito bem pagos, que assumiram a regência das principais cadeiras:

Mandaste vir de toda a parte, com grandes regalias, mestres exímios e munidos das armas de todos os conhecimentos, para que conduzissem as fileiras da multidão de estudantes que renunciavam ao muito sublime conhecimento das coisas em favor do capacete e da couraça, às línguas muito eloquentes em favor dos gládios, aos doutíssimos livros em favor dos escudos, às sempre disponíveis canetas em favor dos dardos (Or. pan., fl. Aiiij).

E por ele a Alma Mater Conimbricense era generosamente sustentada e engrandecida, de tal modo que a sua fama já se estendera pelo mundo inteiro:

Fundada de facto por ti, cresce imensamente com grandes dispêndios. Por ti, príncipe clementíssimo, é generosamente sustentada, ornada e engrandecida. Finalmente, brilhando com a tua administração e autoridade, em todos os estudos das belas letras, encheu já o mundo inteiro com a fama do seu nome (Or. pan., fl. Aijvo).

Inácio de Morais justifica a paixão do rei pela sabedoria com o facto do monarca ter consciência de que Deus não concedeu aos homens nenhum dom 
maior, e que ela é necessária para uma vida honesta e feliz e indispensável ao governo de qualquer nação:

Compreendes, sem dúvida perfeitamente, pelas coisas que na tua adolescência aprendeste de óptimos mestres, que à raça dos mortais não foi dado por Deus muito bom e muito grande nenhum dom maior que a sabedoria. Com efeito, que há de mais útil do que ela? Que há de mais agradável? Que há de mais necessário? Sem a sua ajuda não pode ser conhecida a diferença entre bons e maus, nem a paz pode ser mantida, nem pode manter-se a regra de uma vida honesta e feliz, nem, finalmente, ser governada qualquer nação (Or. pan., fl. Aiiijvo ).

Com este seu amor pela sabedoria, D. João III conseguiu, segundo Inácio de Morais, despertar na gente lusitana, em tempo de paz, o gosto pela obtenção do louro triunfal proveniente das vigílias literárias:

Em suma, fizeste, rei invictíssimo, com que a gente lusitana, embora lute, em guerra contínua, com as nações bárbaras e com os inimigos da religião verdadeira, não procure menos para si, em tempo de paz, o louro triunfal proveniente das vigílias literárias, do que, em tempo de guerra, o que provém do inimigo vencido (Or. pan., fl. Aiiijv ${ }^{\circ}$.

Este entusiasmo régio pelas letras, que levou Inácio de Morais a considerar D. João III o maior patrono e mecenas das letras (Or. pan. fl.C $\left.\mathrm{Cv}^{\circ}\right)$, é tanto mais digno de admiração quanto se sabe que D. João III era, como reconhece o próprio Inácio de Morais "um príncipe não muito culto":

Muitas vezes nos admirávamos de um príncipe não muito culto se entusiasmar tanto num extraordinário amor pelas letras (Or. fun., fl.Aiijvo ).

Estas palavras de Inácio de Morais, proferidas numa oração claramente laudatória, são extremamente importantes, pois funcionam de certo modo como uma prova da sinceridade das palavras do humanista, numa época em que as pessoas nem sempre o eram, elogiando-se habitualmente uns aos outros de forma pouco sincera. Estas palavras parecem-nos também importantes para atribuir valor histórico a estes textos de Inácio de Morais, não esquecendo, contudo, que estamos na presença de textos com objectivos claramente encomiásticos.

D. João III é também retratado como um profundo cultor da justiça, constantemente preocupado em não deixar que se cometessem injustiças contra alguém e que nenhum tumulto ou discórdia crescesse entre os seus cidadãos:

Que direi da tua justiça e equidade, das quais tu és um cultor tão diligente que dedicas todo o teu cuidado e toda a tua preocupação a isto, a saber: que não seja cometido contra alguém uma injustiça ou insulto, e que nenhum tumulto ou discórdia cresça entre os teus cidadãos (Or. pan., fl. Aiiijvº). 
A sua justiça era marcada por uma grande e natural severidade, à qual se juntavam um sentimento de humanidade e uma profunda moderação e clemência:

E embora possuas uma grande e natural severidade, juntas-lhe, todavia, um tal sentimento de humanidade, e apresentas tal moderação, que nem os malfeitores nutrem a esperança da impunidade do crime cometido, nem por sua vez os pobres e os infelizes (quando a ocasião o exige) desconfiam da tua misericórdia (Or. pan., fls. Aiiijv ${ }^{\circ}-$ B).

O rei era particularmente severo no castigo daqueles que ofendiam a magistratura:

Além disso, apontam em teu louvor um facto notável e memorável: o não castigares ninguém mais severamente do que aqueles que ofendem a magistratura, o que fazes, levado, sem dúvida, por justíssima razão. Na verdade, além de que a tua majestade também é ferida quando a magistratura é violada, os que ousarem menosprezar uma vez a magistratura, apossar-se-ão igualmente de uma boa ocasião para cometerem delinquências (Or. pan., fl. B).

Mas, ao contrário do que acontecia com outros príncipes, não confiava a ninguém o direito de condenar à morte sem o seu consentimento:

No entanto, há uma coisa notável que me ocorre à lembrança e que de modo nenhum calarei, é o facto de que, enquanto os outros príncipes da terra confiam aos seus governadores e magistrados o direito de condenar à morte os criminosos, a ninguém, na Lusitânia, concedes esse poder, de tal modo que se possa fixar o negro thêta sem o teu consentimento (Or. pan., fl. $\mathrm{Bv}^{\mathrm{o}}$ ).

A presença simultânea da severidade e da clemência na justiça do rei levam Inácio de Morais a comparar D. João III com Catão e com César. Com o primeiro rivalizava na severidade, com o segundo na clemência:

Por isso, aquilo que Salústio diz de Caio César e de Marco Catão, a saber: que ambos, por virtudes diversas, alcançaram a maior glória; em ti, só, estas diferentes virtudes parecem estar mutuamente de acordo, de tal maneira que rivalizas não só com a severidade de Catão, mas também com a clemência de César (Or. pan., fl.B).

A moderação e a sobriedade do rei são realçadas por Inácio de Morais, nomeadamente a forma frugal como o rei se alimentava e a simplicidade com que se vestia:

Com efeito é claro para todos como aproveitas para as tuas refeições o pouco tempo que sobra dos teus afazeres quotidianos, como te alimentas de forma frugal e comum, e como és de tão grande continência que nunca provaste vinho, mas apenas bebes água pura. É na verdade isto que te invejam não só muitos e grandes chefes, mas sobretudo Alexandre, de quem se diz que algumas vezes cometeu crimes abomináveis por embria- 
guês. Por outro lado, ocupas-te tão pouco com o ornato do corpo que nisto não te distingues quase nada dos teus súbditos. Também não pode ser suficientemente louvada a tua famosa moderação, porque tens sempre cuidado para que não pareça que fizeste algo ao acaso ou com cólera. Além disso, és tão propenso à liberalidade que, entre as tuas outras virtudes, também esta é a tal ponto quase admirável que, como um rio perene, não pode deter-se ( Or. pan., fls. Biiijvo - C).

O passo citado termina com uma especial referência à liberalidade do rei, uma virtude que Inácio de Morais não deixa de realçar, e à qual recorriam inúmeras pessoas para as mais variadas situações:

De facto, quão poucos há, em Portugal, a quem a tua régia liberalidade não ajude? Alguém não tem com que sustentar os seus filhos no estudo das letras; recorre à beneficiência régia. Não tem dote para casar a filha; implora o auxílio do rei. Salvou-se alguém de um naufrágio; calculados os prejuízos, pede o subsídio régio. Falta dinheiro para que alguém obtenha a merecida coroa de loureiro nos estudos; pede o auxílio régio. Desabam templos sagrados; são restaurados à custa do rei. Para quê mais exemplos? Ouvimos dizer que existiu, em Atenas, um lugar que chamavam Pritaneu onde os que serviram bem a nação eram alimentados à custa do estado. Mas, no nosso Portugal, a casa real não só auxilia os que serviram bem o estado, mas também todos os necessitados e infelizes (Or. pan., fl. C).

Uma outra qualidade do rei, bastante conhecida segundo Inácio de Morais, é a coragem ímpar com que ele suportava os golpes que a fortuna adversa lhe foi lançando. Efectivamente, D. João III viu morrerem-lhe os seus dez filhos e quase todos os seus irmãos ${ }^{14}$, e resistiu estoicamente, ao contrário do que aconteceu com figuras tão notáveis como Sertório, Octávio César Augusto ou Alexandre Magno, que nem sempre foram capazes de resistir às perturbações do espírito:

Não é certamente pouco conhecido quão grandes exemplos tu deste também da grandeza de alma e de uma força superior. Com efeito, sempre que a fortuna adversa te lança os seus golpes (o que a infeliz condição humana não pode evitar), com que força, com que moderação, os suportas! Viste, num curto espaço de anos, os cadáveres da tua numerosa descendência amontoados, uns sobre os outros, e os caríssimos filhos roubados pelos fados na própria flor da idade. Viste, repetidas vezes, a morte dos teus caríssimos irmãos e irmãs. Mas, lembrado da condição humana, suportas com igual constância todos estes dolorosíssimos golpes e ( como diz o poeta) "escondes no fundo do coração a dor". Finalmente, a exemplo de David, depois de teres aceitado qualquer tipo de desgraça, alteras o espírito para dar graças à vontade divina. Na verdade, embora sejas digno de toda a prosperidade, se te acontece algo de adverso, não ignoras que te está a ser oferecida ocasião para a paciência cristã, porque as coisas favoráveis mostram os que são felizes e as desfavoráveis os que são grandes.

Esqueça-se, portanto, perante esta tua tão notável virtude, o ilustre Sertório que, embora fosse terrivel na guerra e comandasse as tropas lusitanas, todavia, ao ouvir a notícia da morte da mãe, pouco faltou para morrer de tristeza. 
Esqueça-se César Augusto que, como tivesse sido travada pelos romanos uma batalha infeliz na Germânia, sendo general Quintílio Varo, ficou de tal modo consternado que, com a barba e o cabelo crescido, batendo várias vezes com a cabeça na porta, gritava de forma indigna: "Quintílio Varo, restitui-me as legiões".

Esqueça-se também o grande Alexandre que, quando finalmente voltou a si, lembrando-se do muito vergonhoso assassínio que cometera por embriaguês, não podendo suportar a dor, abstinha-se de comer e preparava a espada para se matar, se não tivesse sido impedido pelos amigos.

Que há, porém, de mais indigno da fama de tão célebres homens, do que suportar com resignação as dores do corpo mas não poder resistir às perturbações do espírito? (Or. pan., fls. $\mathrm{Bv}^{\circ}-\mathrm{Bij}$ ).

Aliás, o ânimo do rei era superior a toda a fortuna pois "nem se elevava com as coisas favoráveis nem sucumbia com as adversas"15.

A esta coragem estóica do rei não devia ser alheia a sua religiosidade, a maior, segundo Inácio de Morais, que alguma vez terá existido num príncipe cristão; pois não só era assíduo na sagrada confissão, mas também aumentou em todo o reino o culto divino, e procurou que fossem observados com mais pureza e sinceridade os ritos e as cerimónias religiosas. Para isso mandou vir de toda a parte prelados que se distinguiam pela pureza de costumes e pela erudição. São as seguintes as palavras de Inácio de Morais:

Além disso, para que abordemos também brevemente a religiosidade, julgo que nunca existiu, num príncipe cristão, nenhuma maior. Ele era assíduo na sagrada confissão, ele aumentou, em toda a Lusitânia, o culto divino, ele procurou que fossem observados com mais pureza e sinceridade os ritos e as cerimónias religiosas. Ele mandava vir de toda a parte os prelados das comunidades e das ordens religiosas que se distinguiam pela pureza de costumes e pela erudição (Or. fun., fl. Aiijvº).

Nos versos 99-100 da elegia à morte de D. João III, Inácio de Morais volta a afirmar que, no mundo inteiro, não houve outro príncipe mais notável no sentimento religioso:

Direi a verdade: em todo o orbe, nenhum outro príncipe foi mais notável no sentimento religioso.

A sua religiosidade não lhe permitia pegar em armas contra os cristãos. Sentia horror às guerras criminosas e injustas. As suas guerras tinham como único objectivo propagar o mais possível a religião cristã, não para mostrar força, mas para ensinar a benevolência; não para dominar com orgulho, mas para olhar pelos vencidos, para os salvar:

Embora comandes gente muito belicosa e sobressaias com os teus recursos, todavia não experimentas as tuas forças contra um qualquer, mas somente contra os inimigos do nome de Cristo. Não pegas em armas ímpias, nem te contaminas com sangue fraterno. 
Com efeito, somos todos irmãos, estamos todos ligados à mesma cabeça, a Cristo, e estamos todos unidos pela aliança da Igreja. Sentes horror às guerras criminosas e injustas, e somente fazes guerras honestas, não para alargares as fronteiras do teu império, mas para que se propague o mais longe possível a religião cristã; não para mostrares força, mas para ensinares a benevolência; não para dominares com orgulho, mas para olhares pelos vencidos no interesse da união da piedade com a justiça, felicíssimo género de vitória, em que os inimigos vencidos, pelo facto de serem vencidos, são salvos, quando de outro modo haveriam de perecer (Or. pan., fl.Bij).

\section{Esta ideia é reiterada na Oratio funebris:}

E por isso, preocupando-se muito pouco com a sua comodidade, não andava em guerra com os cristãos vizinhos, mas antes com os estrangeiros e longínquos inimigos dos cristãos, e fazia isso, na verdade, não porque buscasse glória para si, mas sim para o nome de Cristo, e para que propagasse o seu culto ( o que ele fez) até às mais afastadas regiões do orbe e na maior extensão possível (fls. Aijvo ${ }^{\circ}$-Aiij).

Recorde-se que dilatar a fé e o império era, no século XVI, o ideal da nação, imortalizado por Camões (cf. Os Lusiadas, I, 2). O ideal religioso era como que a alma do povo, não é pois, por isso, de estranhar que D. João III se tenha assumido como o grande paladino da vocação missionária do povo português, levando a religião cristã até às regiões mais afastadas do mundo.

Inácio de Morais apresenta o exemplo de D. João III para criticar as guerras entre cristãos, particularmente as lutas entre Carlos V e Francisco I:

De ti aprendam, portanto, o exemplo da verdadeira força, os que fazem guerras injustas, ou os que, embora sendo cristãos, combatem para perdição mútua. Saibam que a guerra, excepto a que as leis determinam, é um inimigo prejudicial à natureza, que gerou o homem sobretudo para a paz e mútua concórdia. Por isso, Cristo recomenda sempre a paz, porque ela é muito necessária e porque a guerra traz para a nação todo o género de males. Por isso, como nada é mais inconveniente para toda a raça humana do que a guerra, quão mais torpe ela é para um cristão? Daí que a tua piedade mais tenha sobressaído, sem dúvida, no nosso século, porque tu não só sempre desejaste que a paz fosse mantida no teu reino, mas também exortaste à concórdia e paz mútua outros príncipes cristãos separados pela guerra. Embora laços de sangue e outras relações de amizade te pudessem levar à guerra por uma facção ou por outra, todavia permaneceste sempre no mesmo propósito de que a paz deve ser mantida (Or. pan., fl.Bijvo).

É clara, neste passo, a alusão que o humanista faz à guerra entre Carlos $\mathrm{V}$ e Francisco I, os senhores dos dois mais poderosos estados do mundo cristão do seculo XVI. Carlos V, rei de Espanha e imperador da Alemanha, senhor de grande parte da Europa, pretendia dilatar o seu domínio. Contra as suas intenções surgiu, no entanto, Francisco I, rei de França. Ora, D. João III era cunhado de Carlos V, mas também eram antigas e cordiais as relações de Portugal com a França. Nestas circunstâncias não era fácil para D. João III conservar a neutralidade neste 
conflito. No entanto, e apesar das pressões de ambas as partes, D. João III soube, diplomaticamente, manter a sua neutralidade.

Embora amigo da paz, D. João III, imbuído de um espírito de cruzada, não se esquivava à guerra justa e necessária, mas o seu exército não estava ao serviço de guerras entre cristãos, apenas lutava contra os inimigos da religião cristã. Aliás, Inácio de Morais não deixa de salientar que D. João III enviava, para onde quer que fosse necessário, auxílios em defesa da religião:

Não só tens um exército permanentemente em guerra contra os inimigos da religião cristã, como também envias, para onde quer que seja necessário, auxílios em defesa da mesma religião (Or. pan., fl.Biij).

E o humanista aponta alguns exemplos desses auxílios do rei de Portugal para defesa da religião cristã:

No nosso tempo, os turcos assaltavam Rodes, grande cidade da Ásia, desde há pouco fortaleza cristã. Tu foste o primeiro a enviar contra eles uma armada muito bem preparada que, se tivesse sido levada por uma navegação favorável, teria causado, sem dúvida, grande terror aos inimigos.

O mesmo inimigo turco levou também a guerra aos Húngaros, e desde que foste informado disso, ofereces continuamente os teus tesouros e envias para a Germânia legados com muito dinheiro para, a expensas tuas, formarem tropas auxiliares. Como se estivesse a tratar disso, é anunciado, por fim, que, destroçado o exército dos Húngaros e morto o rei Luís, o auxílio estava a ser preparado inutilmente.

Carlos César atravessara para África e atacava a fortaleza de Tunes; imediatamente lhe prestou auxílio uma tua armada bem apetrechada de homens e armas, cuja bravura nessa guerra foi admirável e digna do nome lusitano. E porque as tuas obrigações não te permitiam sair das fronteiras do teu reino, acorreu imediatamente o teu muito valoroso irmão, o príncipe Luís, que juntou o seu exército com o do teu cunhado César (Or. pan., fl. Biij).

Inácio de Morais não deixa de salientar os feitos bélicos dos portugueses sob o comando de D. João III que, embora em pequeno número, submeteram grande parte de África e quase todo o Oriente:

Aumenta também a tua felicidade, rei poderosíssimo, o facto de comandares estes homens que, pela firmeza de espírito e forças do corpo, em nada são inferiores a quaisquer outros homens, e que põem o louvor e a glória acima de todos os bens, sejam eles quais forem, que lhes caibam em sorte. É a partir disto que muitas vezes, reflectindo comigo mesmo nas qualidades e feitos dos nossos homens, ouso afirmar o seguinte: que nenhuns outros igualam tão perfeitamente a "virtus" romana, ou, pelo menos, a reproduzem tão bem. Na verdade, não estou a inventar para agradar, pois algumas destas coisas estão contidas nos velhos livros de história latina; outras, vemo-las todos os dias na nossa época. Com efeito, se se tiver em conta o pequeno número dos portugueses relativamente a um tão grande número de inimigos, quem não se admirará, com razão, de 
tantas duríssimas guerras pelos nossos empreendidas e terminadas com tão feliz sucesso de feitos militares? E de tantas cidades, tantas fortalezas tomadas pela força, grandes tempestades do oceano domadas, novas ilhas, novas regiões desconhecidas e encontradas para o nosso orbe? Em suma, submeteu-se grande parte de África, quase todo o Oriente, para cuja região quase extrema foram levadas as armas lusitanas, e ao alto colocados os estandartes da Santíssima Cruz, até onde não penetrou outrora nem a bravura de César Augusto nem a de Alexandre (Or. pan., fls. Biij-Biijvo ).

\section{CONCLUSÃO}

O amor de D. João III pela piedade, pela justiça, pela religião, pelas letras e pela paz, era tal que levou Inácio de Morais a confessar que quem quer que leia as velhas histórias dos gregos ou dos romanos dificilmente encontrará algum príncipe que possa comparar-se a D. João III:

Se alguém ler as velhas histórias, tanto dos Gregos como dos Romanos, a custo encontrará algum príncipe que possa comparar-se contigo (Or. pan. fls. $\mathrm{C}-\mathrm{Cv}^{\circ}$ ).

Nos quatro epitáfios que se seguem à elegia à morte de D. João III, Inácio de Morais sintetiza as numerosas qualidades do rei. Consegue-o de um modo especial no último desses epitáfios onde, em poucas palavras, consegue abarcar praticamente todas as suas qualidades:

João, pai da pátria, está aqui sepultado, João, terceiro de nome. Clemente, calmo, piedoso, bondoso, cheio de dignidade, de olhar sereno, governando o seu povo com paz tranquila e preservando a justiça e a fé. Com estas qualidades mereceu entrar no reino celeste e gozar de uma paz perene (fl. Biiijvo).

Como acabámos de ver, são muitos e importantes os dados relativos a D. João III, presentes na obra de Inácio de Morais. É, pois, fundamental que estes textos sejam tidos em conta por todos aqueles que se debrucem sobre a vida e a personalidade de D. João III, não esquecendo nunca, no entanto, que estamos perante textos claramente encomiásticos.

\section{NOTAS}

1 Sobre este importante humanista português pouco divulgado, veja-se A. P. Couto, Vida e obra de Inácio de Morais, Coimbra, 1995 (tese de doutoramento, policopiada).

${ }^{2}$ De acordo com as características desta revista, todas as citações que, ao longo deste artigo, fizermos destas duas obras, serão sempre apresentadas em tradução portuguesa, omitindo-se a transcrição do texto latino. No final de cada passo citado indicar-se-á a sua localização na obra latina. 
${ }^{3}$ A acta do Conselho da Universidade em que se tratou da recepção de D. João III e se escolheu Inácio de Morais para proferir a oração de saudação foi publicada pelo prof. Mário Brandão, nas Actas dos Conselhos da Universidade de 1537-1557, Coimbra, 1941-1969, vol.II, parte I, p.270-271. O ambiente que antecedeu e rodeou a visita de D. João III a Coimbra, em Novembro de 1550, foi retratado por A. M. Simões de Castro no estudo intitulado "Vinda de El-Rei D. João $3 .^{\circ}$ a Coimbra no ano de 1550", publicado nos n. ${ }^{\text {s }} 2,3,4$ e 6 do Boletim Bibliográfico da Biblioteca da Universidade, vol. I (1914), nas páginas 78-86, 140-147, 191-194 e 291-294, respectivamente.

${ }^{4}$ A acta do Conselho em que se falou do modo como decorreu a oração de Inácio de Morais foi também publicada pelo prof. Mário Brandão, op. cit., vol.II, parte I, p.274-275.

5 Vd. e. g. Cícero, Partitiones Oratoriae.

- Foram várias as orações panegíricas dedicadas a D. João III na produção literária do séc. XVI. De entre as mais significativas na exaltação da figura do rei e da sua política, destacam-se, para além da de Inácio de Morais: a de António Luís, que é um elogio dos descobrimentos e da paz durante o reinado de D. João III, com especial realce para os temas de filosofia moral e política: Panagyrica oratio elegantissima plurima rerum et historiarum copia referta loanni huius nominis tertio inuictissimo Lusitaniarum regi nuncupata, Antonio Lodouico Vlyssiponensi medico auctore. Vlysiponae. Apud Logdouicum Rotorigium Tipographum.MDXXXIX; a de André de Resende, Oratio habita Conimbricae in Gymnasio Regio anniuersario dedicationis eius die, pronunciada em 1551 no Colégio das Artes e que se assemelha bastante à de Inácio de Morais na apresentação das virtudes régias e a de Diogo de Teive: Oratio in laudem Ioannis Tertii Inuictissimi Lusitaniae et Algarbiorum Regis publice pronunciata Conimbricae, proferida em 1552 e publicada nos Iacobi Teuii Bracarensis opuscula aliquot in laudem Ioannis Tertii Lusitaniae Regis, et principis eius filii, et fratris Ludouici, atque item Sebastiani primi Regis eiusdem nepotis. Quorum sequens pagella catalogum continet. Salmanticae. Excudebant haeredes Ioannis a Iunta Floren. 1558.

7 Após a morte do rei, a 11 de Junho de 1557, o Conselho-mor da Universidade de Coimbra, reunido no dia 15 de Junho, decidiu que se realizassem pomposas comemorações fúnebres, tendo, para o efeito, sido criada uma comissão composta pelos doutores Frei Martinho de Ledesma e Gaspar Gonçalves. Foram também escolhidos os oradores: o doutor Belchior Cornejo para o dia das exéquias e o doutor Manuel da Costa para as "vésperas". (Vd. Mário Brandão, $O$ Colégio das Artes, vol II, Coimbra, 1933, pp.113-116, onde ele descreve as exéquias do rei). A morte de $\mathrm{D}$. João III foi lamentada por vários humanistas, dos quais destacaríamos: André de Resende, na obra intitulada $L$. Andreae Resendii in obitum D. Loannis III Lusitaniae regis conquestio. Permissu et auctoritate Reuerendissimorum patrum Inquisitorum. Olisipone. Apud Ioannem Blauium Typographum Regium. Mense lulio, 1557; e Diogo de Teive, na Oratio funebris in laudem Ioannis tertii inuictissimi Lusitaniae Regis, publicada em 1558 nos já citados opuscula aliquot.

${ }^{8}$ Sempre que nos referirmos a esta obra, fá-lo-emos recorrendo à abreviatura Or. pan.

${ }^{9}$ Foram, de facto, inúmeros os bolseiros enviados por D. João III para escolas estrangeiras, nomeadamente Paris, Salamanca, Roma, Lovaina, etc..

Sobre o interesse de D. João III pela ida de estudantes portugueses para grandes centros de cultura, veja-se J. S. Silva Dias, A política cultural da época de D. João III, Coimbra, 1969, vol.I, pp.347-351.

10 Passaremos a referir-nos a esta oração pela abreviatura $O r$. fun.

1 Passaremos a referir-nos a esta elegia pela abreviatura $E l$.

12 Sobre o conceito de príncipe ideal no século XVI, veja-se Nair N. Castro Soares, O príncipe ideal no século XVI e a obra de D. Jerónimo Osório, Coimbra, INIC, 1994, p.189-290.

13 Vd. id., ibid., p.267-269.

14 De facto, D. João III suportou estoicamente não só a morte de todos os seus filhos: D. Afonso (n. em 24/02/1526; f. com um mês); D. Maria (n. em 15/10/1527; f. em 12/08/1545); 
D. Manuel (n. em 01/11/1531; f. em 14/04/1537); D. Filipe (n. em 25/03/1533; f. em 29/04/1539); D. Dinis (n. em 06/04/1535; f. em 01/01/1537); D. António n. em 09/03/1539; f. em 20/01/1540); D. Duarte (n. em 1521; f. em 11/11/1543); D. João (n. em 03/06/1537; f. 02/01/1554) mas também a de muitos dos seus irmãos: D. Isabel (n. em 24/10/1503; f. em 1/5/1539); D. Beatriz (n. em 31/12/1504; f. em 8/1/1538); D. Fernando (n. em 5/6/1507; f. em 7/11/1534); D. Afonso (n. em 23/4/1509; f. em 21/4/1540); D. Maria (1511-1513); D. Duarte (n. em 7/10/1515; f. em 20/9/1540); D. António (n. em 9/9/1516; f. de tenra idade) e D. Carlos (n. 18/2/1520; f. em 15/4/1521) (Cf. J. V. Serrão, História de Portugal, Lisboa, Editorial Verbo, vol. III, 1980, pp.421-424). Os reis, por se lhes reconhecer autoridade moral em relação ao comum dos mortais, não podiam exprimir a dor que sentiam, sendo, por isso, obrigados a dissimulá-la. Esta dissimulação como que encarna o ideal estóico, tão prezado por reis e príncipes desta época.

15 Cf. Or. fun., fl. Aiiij. 